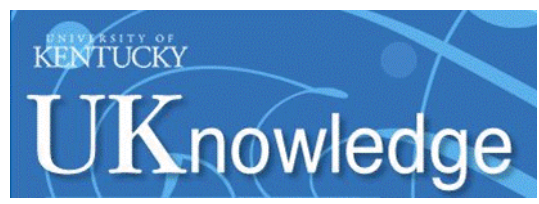

University of Kentucky

UKnowledge

\title{
Adaptation to Climate Change in Mixed Crop-Livestock Farming Systems in Developing Countries
}

Philip K. Thornton

Agriculture and Food Security, Kenya

Mario Herrero

CSIRO, Australia

Follow this and additional works at: https://uknowledge.uky.edu/igc

Part of the Plant Sciences Commons, and the Soil Science Commons

This document is available at https://uknowledge.uky.edu/igc/22/2-8/2

The XXII International Grassland Congress (Revitalising Grasslands to Sustain Our Communities) took place in Sydney, Australia from September 15 through September 19, 2013. Proceedings Editors: David L. Michalk, Geoffrey D. Millar, Warwick B. Badgery, and Kim M.

Broadfoot

Publisher: New South Wales Department of Primary Industry, Kite St., Orange New South Wales, Australia

This Event is brought to you for free and open access by the Plant and Soil Sciences at UKnowledge. It has been accepted for inclusion in International Grassland Congress Proceedings by an authorized administrator of UKnowledge. For more information, please contact UKnowledge@lsv.uky.edu. 


\title{
Adaptation to climate change in mixed crop-livestock farming systems in developing countries
}

\author{
Philip $K$ Thornton $^{A}$ and Mario Herrero ${ }^{B}$ \\ A CGIAR Research Program on Climate Change, Agriculture and Food Security (CCAFS), ILRI, PO Box \\ 30709, Nairobi 00100, Kenya \\ ${ }^{B}$ CSIRO, 306 Carmody Road, St Lucia, QLD 4067, Australia. \\ Contact email: mario.herrero@csiro.au
}

\begin{abstract}
Globally, crop-livestock systems produce over $90 \%$ of the world's milk supply and $80 \%$ of the meat from ruminants. Mixed crop-livestock systems are particularly important for livelihoods and food security, as they provide most of the staples consumed by poor people. These systems will be under considerablepressure in the coming decades to help satisfy the burgeoning demand for food from rapidly increasing populations, particularly in sub-Saharan Africa and South Asia, where rural poverty and hunger are already concentrated. At the same time, the impacts of climate change will be increasingly heavily felt. Increases in temperatures and changes in the amounts and patterns of rainfall are expected, and increased frequency and intensity of climate shocks such as drought, flooding and extreme temperatures are already occurring. The full range of climate change impacts on the mixed crop-livestock systems of the tropics is not well understood, particularly in relation to impacts on food security and vulnerability. There are many ways in which the mixed systems can adapt to climate change, including via increased efficiencies of production that sometimes provide mitigation co-benefits as well. Despite the enormity of the development challenge, effective adaptation in the mixed systems as elsewhere will be inextricably entwined with reducing poverty and enhancing food security, and with the provision of an enabling policy, infrastructural and information environment.
\end{abstract}

Keywords: Resilience, diversification, risk, food security, co-benefits.

\section{Introduction}

Mixed farming systems, in which crops and livestock are integrated on the same farm, are the backbone of smallholder production in the developing countries of the tropics (Thomas 2007). Crop-livestock systems cover some 2.5 billion ha of land globally, of which 1.1 billion ha are rainfed arable lands, 0.2 billion ha are irrigated croplands, and 1.2 billion ha are grasslands (de Haan et al. 1997). Nonruminants are found in some mixed farming systems, but they are usually less important than ruminants (Thomas 2007). Crop-livestock systems produce over $90 \%$ of the world's milk supply and $80 \%$ of the meat from ruminants (Herrero et al. 2013). These systems are typically integrated, in the sense that by-products of one enterprise, such as crop residues, are used by another enterprise such as animal production, which in turn provides a by-product such as manure back to the cropping enterprise (Thomas 2007). Crop-livestock systems are widespread across all agro-ecological zones in developing countries, from the lowlands to the highlands, and they occur under widely disparate climatic and soil conditions. Mixed crop-livestock systems are particularly important for livelihoods and food security. They provide most of the staples consumed by poor people: between $41 \%$ and $86 \%$ of the maize, rice, sorghum and millet, and $75 \%$ of the milk and $60 \%$ of the meat (Herrero et al. 2010). The mixed systems employ many millions of people on farms, in formal and informal markets, throughout what are often long value chains.
While mixed crop-livestock systems are globally of considerable importance, the likely impacts on them of climate change are not that well understood from a developing country perspective, nor is there a lot of specific information as to how mixed systems might adapt in the future. In the next sections, we summarise what is known about the likely impacts of climate change on the mixed systems, and review how smallholders might adapt. We conclude by highlighting some unresolved issues that warrant further research attention.

\section{Impacts of climate change on mixed systems in developing countries}

The impacts of climate change on agricultural and natural systems in general have been outlined in many places, including IPCC (2007). Summaries of the impacts on the commodities and natural resources that fall within the mandate of the international agricultural research centres of CGIAR can be found in Thornton and Cramer (2012), from which much of this section is taken. Higher average temperatures will tend to accelerate the growth and development of plants. Most livestock species have comfort zones between 10 and $30{ }^{\circ} \mathrm{C}$, and at temperatures above this, animals reduce their feed intake 3-5\% per additional degree of temperature. Rising temperatures are not uniformly bad, however, as they may lead to improved crop productivity in parts of the tropical highlands where cool temperatures currently constrain crop growth. Average 
temperature effects are important, but other temperature effects may also be critical. Increased night-time temperatures have negative effects on rice yields, for example, by up to $10 \%$ for each $1^{\circ} \mathrm{C}$ increase in minimum temperature in the dry season. Increases in maximum temperatures can lead to severe yield reductions and reproductive failure in many crops. In maize, for example, each degree day spent above $30{ }^{\circ} \mathrm{C}$ can reduce yield by $1.7 \%$ under drought conditions.

Climate change is already affecting rainfall amounts, distribution, and intensity in many places. This has direct effects on the timing and duration of crop growing seasons, with concomitant impacts on plant growth. Rainfall variability is expected to increase in the future, and floods and droughts will become more common. Changes in temperature and rainfall regime may have considerable impacts on agricultural productivity and on the ecosystem provisioning services provided by forests and agroforestry systems on which many people depend. Climatic shifts in the last few decades have already been linked to changes in the large-scale hydrological cycle. Globally, the negative effects of climate change on freshwater systems are expected to outweigh the benefits of overall increases in global precipitation due to a warming planet.

The atmospheric concentration of $\mathrm{CO}_{2}$, rising from a pre-industrial value of $280 \mathrm{ppm}$, has now topped $400 \mathrm{ppm}$, and has been rising by about 2 ppm per year during the last decade. Many studies show a beneficial effect (' $\mathrm{CO}_{2}$ fertilization') on $\mathrm{C}_{3}$ crops and limited if any effects on $\mathrm{C}_{4}$ plants such as maize and sorghum. Some uncertainty exists concerning the impact of increased $\mathrm{CO}_{2}$ concentrations on plant growth under typical field conditions, and in some crops such as rice, the effects are not yet fully understood. While increased $\mathrm{CO}_{2}$ has a beneficial effect on wheat growth and development, for example, it may also decrease the protein concentration in the grain. In some crops such as bean, genetic differences in plant response to $\mathrm{CO}_{2}$ have been found, and these could presumably be exploited through breeding. In other ecosystems, the impacts are not equivocal: increasing $\mathrm{CO}_{2}$ concentrations lead directly to ocean acidification, which (together with sea-level rise and warming temperatures) is already having considerable detrimental impacts on coral reefs and the communities that depend on them for their food security.

Some of the major impacts of climate change on mixed crop-livestock systems are shown in Table 1 . The heterogeneity in crop response to a changing climate will lead to changes in the quantity and quality of crop residues. Crop residues are a key dry-season feed resource for ruminants in mixed crop-livestock systems, and comprise between 45$60 \%$ of the diets of ruminants in these systems (Blummel et al. 2006). In some conditions, while crop failures may result in no grain, there may still be substantial amounts of stover standing; stover production may not be as affected as grain yield in these cases, depending on the timing of the onset of drought. Reductions in quality and/or quantity may have serious implications for smallholder livestock keepers. Currently there is only limited information on possible climate change impacts on stover production. Total maize stover production and cattle numbers are projected to increase in all countries of East Africa to 2050,
Table 1. Impacts of climate change on mixed crop-livestock production systems in developing countries (from Thornton and Gerber 2010).

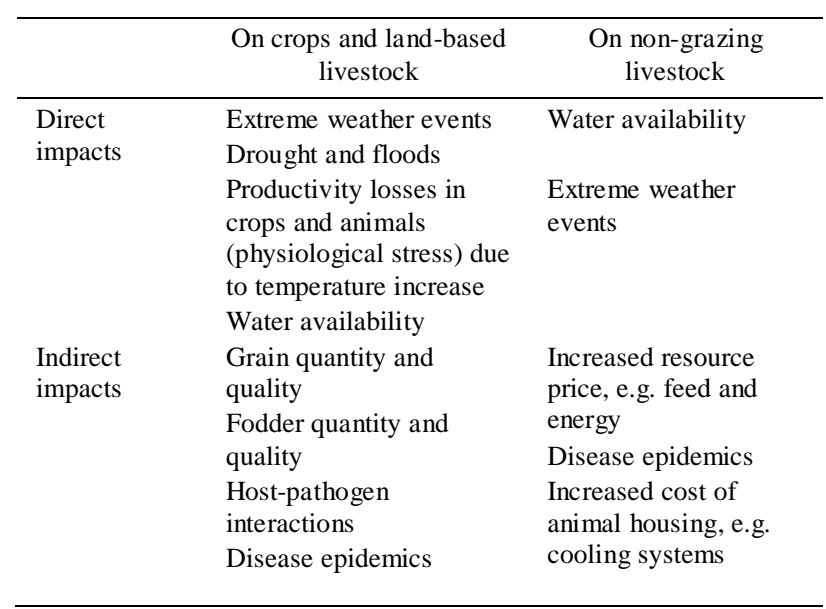

although the harvest index (percentage of total aboveground biomass that is grain) is projected to decrease overall, resulting in a moderate projected decrease in the availability of maize stover per head of cattle to 2050 compared with 2000 (Thornton et al. 2010). The possible impacts of climate change on stover quality are not yet clear. At the same time, changes in temperature, rainfall regime and $\mathrm{CO}_{2}$ levels will affect grassland productivity and species composition and dynamics, resulting in changes in animal diets and possibly reduced nutrient availability for animals. In many situations modifications in grazing systems management may be needed, if livestock keepers are to meet production objectives.

Climate change will have significant impacts on the emergence, spread and distribution of crop and livestock diseases, via pathways such as higher temperatures affecting the rate of development of pathogens or parasites, shifts in disease distribution that may affect susceptible animal populations, and effects on the distribution and abundance of disease vectors (Baylis and Githeko 2006; Gregory et al. 2009). Disease risks may change for a wide variety of reasons in addition to a changing climate, and there are many unknowns concerning the future status of existing livestock diseases and the emergence of new ones.

The impacts of short-term weather variability such as drought on livestock keepers have been widely documented: a highly variable climate with frequent droughts can decimate herds and displace pastoralists (Le Houérou et al. 1988). Increasing climate variability is likely to have substantial impacts on food availability and environmental security for livestock keepers in both pastoral and mixed systems, but as for crops, the nature of changing extremes and increased weather variability and their impacts on livestock productivity and household food security are largely unknown.

Overall, our current understanding of what the impacts of climate change may be on mixed systems in developing countries is incomplete, particularly related to the interactions and trade-offs between different household enterprises and how these may play out in relation to food security and incomes (Thornton et al. 2009). Nevertheless, it is clear that the impacts of changes in climate and climate variability on agricultural production will have substantial 
effects on smallholder farmers in many parts of the tropics and subtropics, and the resulting reduced food security potentially will increase the risk of hunger and undernutrition (HLPE 2012). While many of the people who are likely to be adversely affected may have only limited capacity to adapt to climate change or to the many other stressors that may affect them, a wide range of adaptation responses is possible, some of which are outlined in the next section.

\section{Adapting to climate change in the mixed systems}

Agricultural producers may respond to the threats posed by climate change in different ways; these may be technological, such as the use of more drought-tolerant crops; behavioural, such as changes in dietary choice; managerial, such as implementing different farm management practices; and policy-related, such as market and infrastructure development (IPCC 2007). There are many ways to classify adaptation options, but here we briefly consider three types (admittedly overlapping) of response by households that seem particularly relevant for the mixed systems: increaseing system resilience, diversification, and risk management. In some of these cases, there may be import-ant mitigation co-benefits, and we highlight these too.

\section{Increasing the resilience of the mixed systems}

FAO (2010) describes several ways in which the overall efficiency and resilience of crop and livestock production systems can be enhanced in the face of climate change. For example, appropriate soil and nutrient management, through composting manure and crop residues, more precise matching of nutrients with plant needs, controlled release and deep placement technologies, and using legumes for natural nitrogen fixation, can increase the yields and resilience of crops, while reducing the need for synthetic fertilizers (with the co-benefit of reducing the greenhouse-gas (GHG) emissions associated with their use). In situations with decreasing rainfall and increasing rainfall variability, there are many ways of improving water harvesting and retention, through the use of pools, dams, pits, retaining ridges, and increasing soil organic matter to raise the water retention capacity of soils. Improving ecosystem management and biodiversity can provide several ecosystem services, leading to more resilient, productive and sustainable systems that may also contribute to reducing GHGs. These services include the control of pests and disease, regulation of microclimate, decomposition of wastes, regulation of nutrient cycles, and crop pollination, for instance. There is often considerable genetic variability in domestic crops and livestock, and characteristics such as ability to withstand temperature extremes, drought, flooding and pests and diseases are often at least partially genetically controlled. The utilization of different crops and breeds and their wild relatives is fundamental in developing resilience to climate shocks and longer-term climate change. Efficient harvesting and early transformation of agricultural produce can reduce post-harvest losses and preserve food quantity, quality and nutritional value of the product. Food processing allows surplus to be stored and sales staggered, and can add resilience to agricultural systems by smoothing food security and income variability.

Changes in agricultural inputs and the way farmers use them may be able to more than offset projected yield declines through the use of some of these options (irrigateion water, higher-temperature-tolerant crop varieties and so on) as well as through planting date modifications (Crespo et al. 2011). The addition of trees to the farming system can contribute significantly to increasing resilience in the face of climate change, partly by providing the rural poor with a broader set of options for securing both food and income (Sunderland 2011).

In addition to positive impacts on the rate of carbon sequestration in tropical systems (Albrecht and Kandji 2003), the leaves of some tree and legume species can significantly improve the diets of ruminant livestock because of their relatively high nutritive value and digestibility. A ruminant diet that is higher in quality will reduce the methane output per unit of product; this means that target quantities of animal product can be obtained for lower overall methane emissions and usually with fewer animals (Thornton and Herrero 2010). Trees and legumes on mixed crop-livestock farms thus serve a wide variety of purposes, and can help to reduce the vulnerability and increase the resilience of farming systems while providing substantial mitigation benefits as well (FAO 2010; Bryan et al. 2013). There is growing evidence that natural resource management through agroforestry can lead to improved social protection and resilience (Chaudhury et al. 2011).

Mixed crop-livestock systems may also provide considerable benefits at the sectoral scale as well as at the household scale. A recent study found that autonomous, transformational shifts in livestock production from grassland-based systems to more productive local mixed systems could save $162 \mathrm{M}$ ha of natural land by 2030 and decrease GHG emissions by $736 \mathrm{Mt} \mathrm{CO}_{2}$-eq annually, on a global basis, while increasing production efficiencies in many developing countries and decreasing market prices, compared to a baseline scenario with no system transitions (Havlik et al. 2013a). A catalyst for these changes is the bridging of yield gaps of certain crops, which will reduce the price of grains and the costs of more intensive feeding management practices implemented in the mixed systems, especially in temperate and humid regions (Havlik et al. 2013b).

\section{Diversification}

Diversification may be of different types. Agricultural diversification occurs when more species, plant varieties or animal breeds are added to a given farm or farming community, and this may include landscape diversification - different crops and cropping systems interspersed in space and time. Livelihood diversification may occur when farming households are involved in more and different (non-agricultural) activities, for instance by taking up a job in the city, setting up a shop, or by starting to process farm products. Both agricultural and non-agricultural forms of diversification may be highly relevant for helping to adapt to climate change, in terms of both helping to smooth out short-term household income fluctuations and providing households with a broader range of options to address future change (Thornton et al. 2013). 
While diversification can be an important element of climate change adaptation, there is surprisingly limited information available that can be used to guide farmers and farming communities as to how best to manage diversification possibilities. What works in particular situations is highly dependent on the geographical and socio-economic context of the specific farming system. For example, crop diversification has been found to be most beneficial in situations where crop growing conditions are neither so marginal that they limit diversification options nor so good as to allow the growing of a single high-return crop (Kandulu et al. 2012). Diversification may also be appropriate in the relatively intensive mixed systems of western Kenya, where poverty rates are high and households obtain some $65 \%$ of their income from off-farm sources (Waithaka et al. 2006). The main cash crop is tea, and in addition to food crops such as maize, beans, and bananas, income from dairying is important for many households, from local Zebu animals. Claessens et al. (2012) evaluated the possible impacts of climate change from a variety of climate models and GHG emission scenarios to 2050 on households in this region. Climate change is likely to result in highly negative economic impacts on many households, but the addition of relatively high yielding dual-purpose sweet potato varieties to the farming system, the roots being used for food and the vines as a livestock feed, could partially offset some of these negative consequences. Part of this effect comes about through increased milk production as a result of feeding sweet potato vines to lactating animals (Claessens et al. 2012).

Another study looked at recent and possible future climate-induced livelihood transitions in the mixed extensive systems of East Africa. Human diets at 12 study sites in Kenya, Tanzania and Uganda have changed considerably over the last 40 years, and cropping has been taken up by increasing numbers of pastoral households, even in marginal places where cropping is very risky (Fig. 1). Maize and legumes predominate, but some householders are increasing their crop and diet diversity, particularly in locations with annual rainfall higher than $800 \mathrm{~mm}$. Although many householders have some knowledge of drought-tolerant crops, few cultivate millet, sorghum and cassava. A critical requirement for foodinsecure households in these sites is knowledge transfer concerning the growing and utilisation of unfamiliar and non-traditional crops (Rufino et al. 2013).

For the future, there must be limits as to how far existing agricultural systems can be modified, and thresholds can be envisaged beyond which climate change may be so great that coping ranges and buffering capacities are exceeded. In such cases, ensuring the food security and wellbeing of such mixed farming communities as these may require considerable changes in livelihood strategies, the provision and utilisation of safety nets, and/or a broadening of income-generating opportunities, where this is feasible.

\section{Risk management}

While climate change is expected to result in increased climate variability (IPCC 2012), there are many unknowns regarding the nature of this increased variability. Floods and droughts may lead to complete destruction of crops, while increased frequency of droughts may result in decreased herd sizes because of increased mortality and poorer reproductive performance, severely compromising food security. Increasingly, climate variability may also have substantial impacts on environmental security, as the potential exists for conflicts over livestock assets and natural resources to escalate in the future.

There are several ways in which effective risk management may be able to help households in the mixed systems to adapt to climate change (Thornton et al. 2011). One example is the use of weather information. There has for

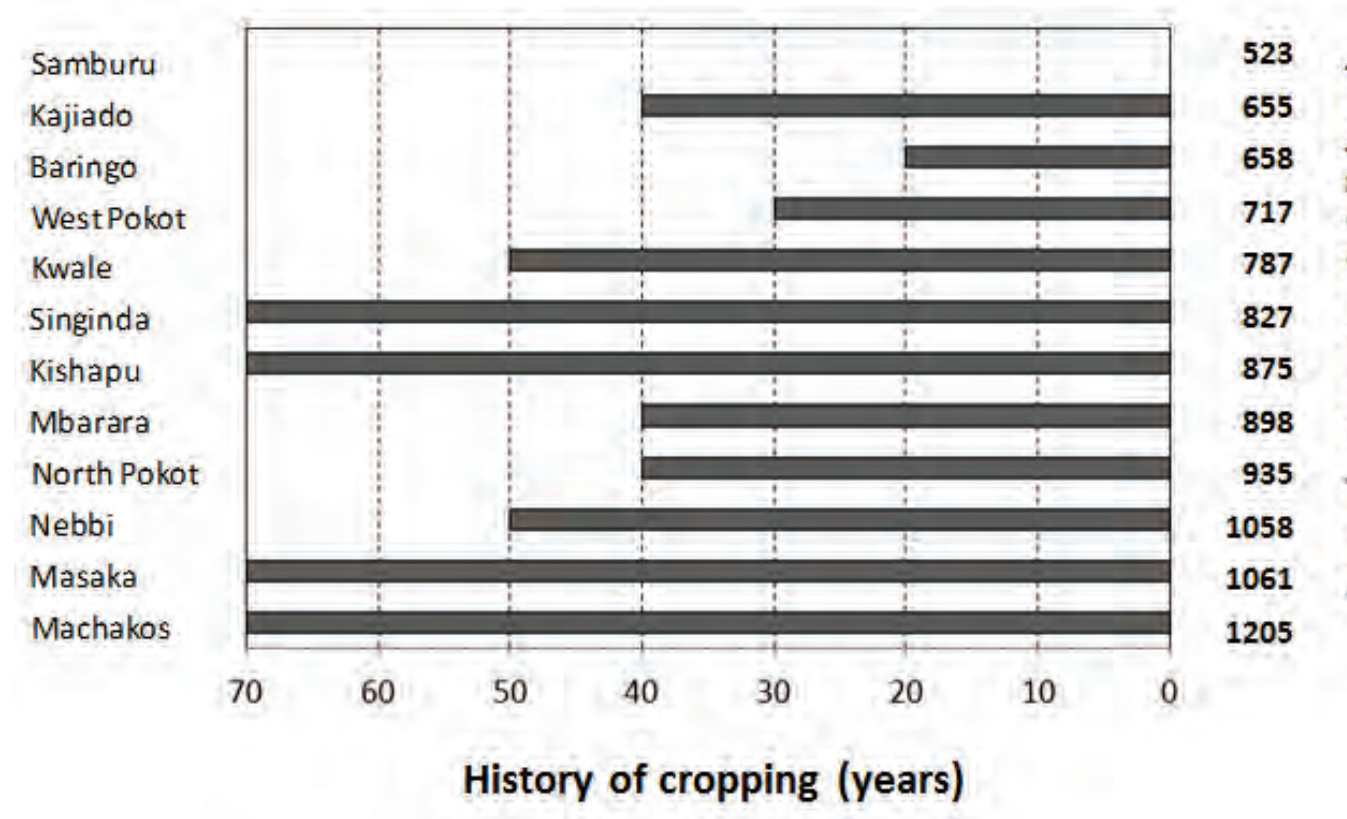

Figure 1. History of cropping in years at each of 12 study sites in Kenya, Uganda and Tanzania, organised by annual rainfall gradient (Rufino et al. 2013). 
several years now been an effective collaboration between government agencies, research institutions, media, extension services, and farmers in Mali, which was started because rural communities needed help in managing the risks associated with rainfall variability (Hellmuth et al. 2007). Ten-day bulletins are produced by multidisciplinary working groups, which provide the basis for information and advice to farmers as well as to national policy makers on the food security status of the country. They are disseminated in various ways, and report on the state of crops, water resources, and weather conditions, as well as crop health issues, pastoral issues, animal husbandry, and agricultural markets, in addition to predicting future conditions. When farmers have good climate information, they are able to make better management decisions that can lead to higher yields and incomes (Hellmuth et al. 2007). There are some issues related to the effectiveness of climate forecasts for crop and livestock management that still need to be addressed, particularly with regard to effective mechanisms for the delivery and utilisation of this type of information, but progress is being made in several countries in sub-Saharan Africa on this front (Hansen et al. 2011). A second example is livestock insurance schemes that are weather-indexed (i.e. policy holders are paid in response to 'trigger events' such as abnormal rainfall or high local animal mortality rates). Insurance schemes for crops are quite widespread, but there are few examples of functioning schemes for livestock. Recent developments in East Africa in index-based livestock insurance highlight the potential for public-private partnerships in situations where the incentives and risks involved do not make it feasible for the private sector alone. Index-based insurance schemes based on satellite imagery are being piloted in several areas of drought-prone northern Kenya and southern Ethiopia (Chantarat et al. 2012).

Refining risk management techniques to make adaptation more effective is likely to include a blend of the old and the new. Farmers in the tropics have a long history of coping with climate variability and have developed many different ways of addressing the issue (Matlon and Kristjanson 1988). At the same time, there are several tools and approaches that are now available that can be used to develop and fine-tune climate risk management strategies that are specifically tailored to stakeholders' needs, including short- and medium-term weather forecasting (Hansen et al. 2011).

\section{Conclusions}

The mixed crop-livestock systems of the tropics are critical for the current food security of large numbers of people. In view of expected population growth and growth in demand for food in the coming decades (Rosegrant et al. 2009), this role is unlikely to change significantly in the foreseeable future, particularly in south Asia and sub-Saharan Africa (Herrero et al. 2012). Thornton et al. (2013) highlight several major categories for priority actions that can be taken to support stakeholders from farm to national and international level to identify and implement adaptation responses: promoting agricultural technologies and innovations, under the rubric of sustainable intensification (Garnett et al. 2013); strengthening local institutions, in particular with reference to information generation and dissemination to producers, risk management, and collective action (McCarthy et al. 2011); and achieving coordinated and informed policies, particularly related to the linking of research and policy.

As noted above, there are considerable gaps in our understanding of how climate change may impact mixed crop-livestock systems in the tropics, particularly the interactions between changes in temperature, rainfall and atmospheric carbon dioxide concentrations and their effect on agricultural productivity, and resultant changes in the incidence, intensity and spatial distribution of important weeds, pests and diseases. Similarly, the impacts of increases in climate variability on the mixed systems and smallholders' food security are largely unknown. At the same time, the prognosis for robust quantification any time soon of changes in weather and climate variability over short temporal and spatial scales is gloomy (Ramirez et al. 2013). This suggests that the impacts modelling community will need to become increasingly creative in asking questions that have actionable answers from the perspective of agricultural decision makers at all levels.

The policy environment within which smallholders operate is likely to change substantially in the future, in response to many drivers. These include the need to move to more intensive, lower-carbon agricultural systems; the increasing competition for increasingly scarce resources such as water and land; the trade-offs required between agricultural production for human food, animal feed, and biofuels; and the involvement of smallholders in international carbon markets once solutions have been found for the associated institutional issues (Rosegrant et al. 2009). Such shifts may have enormous impacts on smallholder mixed farming systems, and better understanding of likely impacts at the household level will be vital in identifying and targeting the alternatives that can help farmers raise incomes, enhance food security and sustain their natural resource base in the future.

\section{References}

Albrecht A, Kandji ST (2003) Carbon sequestration in tropical agroforestry systems. Agriculture, Ecosystems and Environment 99, 15-27.

Baylis M, Githeko AK (2006) The effects of climate change on infectious diseases of animals. London: Foresight Project on Detection of Infectious Diseases, Department of Trade and Industry, UK Government, pp. 35.

Blummel M, Hanson J, Herrero M, Fernandez-Rivera R, Hansen H, Bezkorowajnyj P (2006) ILRI Strategy on Feed Resources. Nairobi: International Livestock Research Institute, pp. 20.

Bryan E, Ringler C, Okoba B, Koo J, Herrero M, Silvestri S (2013) Can agriculture support climate change adaptation, greenhouse gas mitigation and rural livelihoods. Evidence from Kenya. Climatic Change 118, 151-165.

Chantarat S, Mude AG, BarrettCB, Carter MR (2012) Designing index-based livestock insurance for managing asset risk in northern Kenya. Journal of Risk and Insurance 80, 205-237.

Chaudhury M, Ajayi OC, Hellin J, Neufeldt H (2011) Climate change adaptation and social protection in agroforestry systems: enhancing adaptive capacity and minimizing risk of drought in Zambia and Honduras. ICRAF Working Paper 137. Nairobi, Kenya: World Agroforestry Centre (ICRAF).

Claessens L, Antle JM, Stoorvogel JJ, Thornton PK, Herrero M 
(2012) Agricultural system level assessment of climate change adaptation strategies in resource-poor countries. Agricultural Systems 111, 85-95.

Crespo O, Hachigonta S, Tadross M (2011) Sensitivity of southern African maize yields to the definition of sowing dekad in a changing climate. Climatic Change 106, 267-283.

De Haan C, Steinfeld H, Blackburn H (1997) Livestock and the Environment: Finding a Balance, Eye, Suffolk: WREN media.

Food and Agriculture Organization of the United Nations (FAO) (2010) Climate-Smart Agriculture: Policies, Practices and Financing for Food Security, Adaptation and Mitigation. Rome, Italy.

Garnett T, Appleby MC, Balmford A, Bateman IJ, Benton TG, Bloomer P, Burlingame B, Dawkins M, Dolan L, Fraser D, Herrero M, Smith P, Thornton PK, Toulmin C, Vermeulen SJ, Godfray HCJ (2013) Sustainable intensification in agriculture: navigating a course through competing priorities. Science 341, 33-34.

Gregory PJ, Johnson SN, Newton AC, Ingram JSI (2009) Integrating pests and pathogens into the climate change/food security debate. Journal of Experimental Botany 60, 28272838.

Hansen JW, Mason SJ, Sun L, Tall A (2011) Review of seasonal climate forecasting for agriculture in sub-Saharan Africa. Experimental Agriculture 47 (2), 205-240.

Havlík P, Valin H, Herrero M, Obersteiner M, Schmid E, Rufino M, Mosnier A, Böttcher H, Frank S, Fritz S, Fuss S, Kraxner F, Notenbaert A, Thornton P K (2013a) Climate change mitigation through livestock system transitions. Proceedings of the National Academy of Sciences (submitted).

Havlik P, Valin H, Mosnier A, Obersteiner M, Baker J, Herrero M, Rufino M, Schmidt E (2013b) Crop productivity and the global livestock sector: implications for land use change and greenhouse gas emissions. American Journal of Agricultural Economics 95, 442-448.

Hellmuth ME, Moorhead A, Thomson M, Williams J (2007) Climate risk management in Africa: Learning from practice. Palisades, New York: International Research Institute for Climate and Society (IRI).

Herrero M, Thornton PK, Notenbaert AM, Wood S, Msangi S, Freeman HA, Bossio D, Dixon J, Peters M, van de Steeg J, Lynam J, Rao PP, Macmillan S, Gerard B, McDermott J, Seré C, Rosegrant M(2010) Smart investments in sustainable food production: revisiting mixed crop-livestock systems. Science 327, 822-825.

Herrero M, Thornton PK, Notenbaert AM, Msangi S, Wood S, Kruska R, Dixon J, Bossio D, van de Steeg J, Freeman HA, Li X, Rao PP (2012) Drivers of change in crop-livestock systems and their potential impacts on ecosystems services and human well-being to 2030. Study commissioned by the CGIAR Systemwide Livestock Programme. International Livestock Research Institute, Nairobi, Kenya, 114 p.

Herrero M, Havlík P, Valin H, Notenbaert AM, Rufino M, Thornton PK, Blummel M, Weiss F, Obersteiner M (2013) Global livestock systems: biomass use, production, feed efficiencies and greenhouse gas emissions. Proceedings of the National Academy of Sciences (in press).

HLPE (High Level Panel of Experts) (2012) Food security and climate change. A report by the High Level Panel of Experts on Food Security and Nutrition of the Committee on World Food Security, Rome 2012.

IPCC (Intergovernmental Panel on Climate Change) (2007) Climate change 2007: impacts, adaptation and vulnerability. Contribution of working group II to the fourth assessment report of the intergovernmental panel on climate change, MLParry, OF Canziani, JP Palutikof, PJ van der Linden and CE Hanson (eds), Cambridge University Press.

IPCC (Intergovernmental Panel on Climate Change) (2012)
Managing the Risks of Extreme Events and Disasters to Advance Climate Change Adaptation. A Special Report of Working Groups I and II of the Intergovernmental Panel on Climate Change, CB Field, V Barros, TF Stocker, D Qin, DJ Dokken, KL Ebi, MD Mastrandrea, KJ Mach, G-K Plattner, SK Allen, M Tignor, PM Midgley (eds). Cambridge University Press, 582 pp.

Kandulu JM, Bryan BA, King D, Connor JD (2012) Mitigating economic risk from climate variability in rain-fed agriculture through enterprise mix diversification. EcologicalEconomics 79, 105-112.

Le Houérou HN, Bingham RL, Skerbek W (1988) Relationship between the variability of primary production and the variability of annual precipitation in world arid lands. Journal of Arid Environments 15, 1-18.

Matlon P and Kristjanson P (1988) Farmer's strategies to manage crop risk in the West African semi-arid tropics. In "Challenges in Dryland Agriculture: a Global Perspective". Proceedings of the International Conference on Dryland Farming, Bushland, Texas USA, August 15-19. (Eds PW Unger, WR Jordan, TV Sneed, RW Jensen) pp. 604-606.

McCarthy N, Lipper L, Branca G (2011) Climate-Smart Agriculture: Smallholder Adoption and Implications for Climate Change Adaptation and Mitigation. MICCA Working paper 4, Food and Agriculture Organization of the United Nations, Rome.

Ramirez-Villegas J, Challinor AC, Thornton PK, Jarvis A (2013) Implications of regional improvement in global climate models for agricultural impacts research. Environmental Research Letters 8, 024018.

Rosegrant MW, Fernandez M, Sinha A, Alder J, Ahammad H, de Fraiture C, Eickhout B, Fonseca J, Huang J, Koyama O, Omezzine AM, Pingali P, Ramirez R, Ringler C, Robinson S, Thornton PK, van Vuuren D, Yana-Shapiro H, Eb K, Kruska R, Munjal R, Narrod C, Ray S, Sulser T, Tamagno C, van Oorschot M, Zhu T (2009) Looking into the future for agriculture and AKST (Agricultural Knowledge Science and Technology), in BD McIntyre, HR Herren, J Wakhungu and RT Watson (eds), Agriculture at a Crossroads, Washington DC: Island Press, pp. 307-376.

Rufino MC, Thornton PK, Ng'ang'a SK, Mutie I, Jones PG, van Wijk MT, Herrero M (2013). Transitions in agro-pastoralist systems of East Africa: impacts on food security and poverty. Global Environmental Change (submitted).

Sunderland TCH (2011) Food security: Why is biodiversity important? International Forestry Review 13 (3), 265-274.

Thomas D (2007) Crop-ruminant systems and interactions in the tropics. Nairobi, International Livestock Research Institute, pp. 33.

Thornton PK, van de Steeg J, Notenbaert A, Herrero M (2009) The impacts of climate change on livestock and livestock systems in developing countries: a review of what we know and what we need to know. Agricultural Systems 10, 113127.

Thornton PK, Herrero M (2010) The potential for reduced methane and carbon dioxide emissions from livestock and pasture management in the tropics. Proceedings of the National Academy of Sciences 107, 19667-19672.

Thornton PK, Gerber P (2010) Climate change and the growth of the livestock sector in developing countries. Mitigation and Adaptation Strategies for Global Change 15, 169-184.

Thornton PK, Jones PG, Alagarswamy A, Andresen J, Herrero M (2010) Adapting to climate change: agricultural system and household impacts in East Africa. Agricultural Systems 103, 73-82.

Thornton PK, Herrero M, Jones PG (2011) Adaptation to climate change in mixed crop-livestock farming systems in developing countries. Chapter 18 (pp 402-419) In "Handbook on Climate Change and Agriculture" (eds R 
Mendelsohn and A Dinar). Elgar, UK.

Thornton P, Cramer L (eds), 2012. Impacts of climate change on the agricultural and aquatic systems and natural resources within the CGIAR's mandate. CCAFS Working Paper 23. CGIAR Research Program on Climate Change, Agriculture and Food Security (CCAFS). Copenhagen, Denmark. Available online at: www.ccafs.cgiar.org

Thornton PK, Lipper L, Baas S, Cattaneo A, Chesterman S, Cochrane K, de Young C, Ericksen P, van Etten J, de Clerck
F, Douthwaite B, DuVal A, Fadda C, Garnett T, Gerber P, Howden M, Mann W, McCarthy N, Sessa R, Vermeulen S, Vervoort J (2013) How does climate change alter agricultural strategies to support food security? Background paper for the conference "Food Security Futures: Research Priorities for the 21st Century”, 11-12 April 2013, Dublin.

Waithaka MM, Thornton PK, Shepherd KD, Herrero M (2006) Bio-economic evaluation of farmers' perceptions of viable farms in western Kenya. Agricultural Systems 90, 243-271. 